\title{
Potensi Sengketa Kewenangan Lembaga Negara dan Penyelesaiannya di Mahkamah Konstitusi
}

\author{
Ni'matul Huda \\ Fakultas Hukum Universitas Islam Indonesia \\ Jln. Tamansiswa No. 158 Yogyakarta \\ penerbitan.fh@uii.ac.id
}

\begin{abstract}
The presence of various state institutions and independent state institutions (state commissions) after the reformation era in 1998 often leads to tensions or disputes over the authority among state institutions, both at central and regional. The problems to be studied were, first, why can post-reformation state institutions have dispute over their respective authorities? Second, how is the settlement of the dispute over the authority of state institutions at the Constitutional Court? This research was a normative research, with statute and case approaches. The primary legal materials were in the form of Constitutional Court decisions related to the dispute over the authority of state institutions. This study concluded, first, the emergence of the disputes over the authority of state institutions is due to the fact that the establishment of independent state institutions has revoked or reduced some of the authority possessed by the institutions that have previously existed. In addition, the regional autonomy policy also has the potential to cause authority disputes between the Regional Government and the Central Government. Second, even though the Constitutional Court has filed a petition for 25 cases of state institutions' disputes, the Constitutional Court has only granted 1 (one) case namely Case No.03/SKLN-X/2012, namely the dispute over authority between KPU and the Regional Government of Papua, namely the Regional House of Representative of Papuan (Respondent I) and the Governor of Papua (Respondent 2).
\end{abstract}

Keywords: Authority dispute; state institutions; constitutional court

\section{Abstrak}

Kehadiran berbagai lembaga negara dan lembaga negara independen (komisi negara) pasca reformasi 1998 seringkali memunculkan ketegangan atau pun persengketaan kewenangan antar lembaga negara, baik yang di Pusat maupun di Daerah. Permasalahan yang akan diteliti, pertama, mengapa lembaga-lembaga negara pasca reformasi dapat bersengketa atas kewenangan yang dimilikinya masing-masing? Kedua, bagaimana penyelesaian sengketa kewenangan lembaga negara di Mahkamah Konstitusi? Penelitian ini menyimpulkan, pertama, munculnya sengketa kewenangan lembaga negara disebabkan lahirnya lembaga-lembaga negara independen ini telah mencabut atau mengurangi sebagian dari kewenangan yang dimiliki dari lembagalembaga yang telah ada sebelumnya. Di samping itu, adanya kebijakan otonomi daerah juga berpotensi menimbulkan sengketa kewenangan antara Pemerintah Daerah dengan Pusat. Kedua, meskipun Mahkamah Konstitusi telah menyidangkan permohonan sengketa lembaga negara sebanyak 25 perkara, namun Mahkamah Konstitusi hanya mengabulkan 1 perkara yakni yakni Perkara No. 03/SKLN-X/2012, yaitu sengketa kewenangan antara KPU dengan Pemerintah Daerah Papua, yakni DPR Papua (Termohon I) dan Gubernur Papua (Termohon 2).

Kata-kata Kunci: Sengketa kewenangan; lembaga negara; mahkamah konstitusi 


\section{Pendahuluan}

Setelah dilakukan perubahan terhadap UUD 1945, definisi dan pengertian tentang lembaga negara sangat beragam, tidak lagi bisa hanya dibatasi pada tiga lembaga legislatif, eksekutif dan yudikatif. Dalam naskah UUD Negara Republik Indonesia Tahun 1945 (UUD NRI Tahun 1945), organ-organ yang dimaksud, ada yang disebut secara eksplisit namanya, dan ada pula yang disebutkan eksplisit hanya fungsinya. Ada pula lembaga atau organ negara yang disebut baik namanya maupun fungsi atau kewenangannya akan diatur dengan peraturan yang lebih rendah. ${ }^{1}$ Di tingkat pusat, dapat dibedakan dalam empat tingkatan kelembagaan, yaitu: ${ }^{2}$

1. Lembaga yang dibentuk berdasarkan UUD yang diatur dan ditentukan lebih lanjut dalam atau dengan UU, Peraturan Pemerintah, Peraturan Presiden, dan Keputusan Presiden;

2. Lembaga yang dibentuk berdasarkan undang-undang yang diatur atau ditentukan lebih lanjut dalam atau dengan Peraturan Pemerintah, Peraturan Presiden, dan Keputusan Presiden;

3. Lembaga yang dibentuk berdasarkan Peraturan Pemerintah atau Peraturan Presiden yang ditentukan lebih lanjut dengan Keputusan Presiden;

4. Lembaga yang dibentuk berdasarkan Peraturan Menteri yang ditentukan lebih lanjut dengan Keputusan Menteri atau keputusan pejabat di bawah Menteri.

Di dalam praktek, tidak jarang ditemui adanya perselisihan atau persengketaan antara satu lembaga dengan lemabaga negara lainnya, atau antara lembaga negara dengan komisi negara, atau antara pemerintah daerah dengan pemerintah pusat.

Dalam sejarah ketatanegaraan Indonesia sebelum adanya perubahan (tahap ketiga) UUD 1945 pada 2001, belum ada aturan mengenai mekanisme penyelesaian sengketa kewenangan antarlembaga negara. Lembaga yang memiliki kewenangan untuk memberi putusan terhadap sengketa kewenangan antarlembaga negara tersebut juga belum ada. Karena itu selama masa tersebut belum ada preseden dalam praktek ketatanegaraan Indonesia mengenai penanganan sengketa kewenangan antarlembaga negara. Barulah setelah adanya perubahan tahap ketiga

${ }^{1}$ Jimly Asshiddiqie, Menuju Negara Hukum Yang Demokratis, Sekretariat Jenderal dan Kepaniteraan Mahkamah konstitusi, Jakarta, 2008, hlm. 185.

${ }^{2}$ Jimly Asshiddiqie, Perkembangan dan Konsolidasi Lembaga Negara Pasca Reformasi, Sekretariat Jenderal dan Kepaniteraan Mahkamah Konstitusi RI, Jakarta, 2006, hlm. 50. 
UUD 1945, yang mengadopsi pembentukan lembaga negara Mahkamah Konstitusi (MK) yang salah satu kewenangannya adalah memutus sengketa kewenangan antarlembaga negara yang kewenangannya diberikan oleh UUD 1945, sistem ketatanegaraan Indonesia memiliki mekanisme penyelesaian jika terjadi sengketa kewenangan antarlembaga negara. ${ }^{3}$

Sejak 2004 hingga 2016, permohonan sengketa kewenangan lembaga negara (SKLN) yang diajukan ke Mahkamah Konstitusi sebanyak 25 (dua puluh lima) perkara dengan berbagai variasi permasalahan yang disengketakan dan juga diajukan oleh pemohon yang beragam pula. Jika dilihat dari jumlah perkara SKLN yang diajukan ke Mahkamah Konstitusi, data tersebut menarik untuk dikaji apa motif pengajuan SKLN tersebut dan bagaimana Mahkamah Konstitusi menyelesaikannya.

\section{Rumusan Masalah}

Berdasarkan uraian tersebut di atas, maka permasalahan yang hendak diteliti sebagai berikut. Pertama, mengapa lembaga-lembaga negara dapat bersengketa atas kewenangan yang dimilikinya masing-masing? Kedua, bagaimana mekanisme penyelesaiannya di Mahkamah Konstitusi?

\section{Tujuan Penelitian}

Penelitian ini bertujuan untuk mengetahui dan menganalisis: pertama, latar belakang munculnya sengketa kewenangan lembaga negara. Kedua, penyelesaian sengketa kewenangan lembaga negara di Mahkamah Konstitusi.

\section{Metode Penelitian}

Penelitian ini adalah penelitian normatif. Bahan hukum primer yang digunakan dalam penelitian ini berupa UUD NRI Tahun 1945, putusan-putusan Mahkamah Konstitusi terkait sengketa kewenangan lembaga negara, UU No. 8 Tahun 2011 tentang Perubahan Pertama atas UU No. 24 Tahun 2003 tentang Mahkamah Konstitusi, dan PMK No. 8/2006 tentang Pedoman Berperkara SKLN di Mahkamah Konstitusi. Adapun bahan hukum sekunder yang digunakan berupa

${ }^{3}$ Jimly Asshiddiqie, Sengketa Kewenangan Antarlembaga Negara, Konpress, Jakarta, 2005, hlm. 2. 
risalah sidang perubahan UUD NRI Tahun 1945, hasil penelitian terdahulu, literatur, jurnal, dan media massa. Teknik pengumpulan bahan hukumnya dilakukan dengan cara studi kepustakaan. Pendekatan yang digunakan dalam penelitian ini berupa pendekatan perundang-undangan dan pendekatan kasus. Kedua pendekatan tersebut digunakan untuk menganalisis mengapa lembagalembaga negara itu bersengketa atas kewenangan yang dimilikinya masingmasing, serta bagaimana penyelesaiannya di Mahkamah Konstitusi selama ini.

\section{Hasil Penelitian dan Pembahasan}

\section{Perkembangan Lembaga Negara dan Potensi Sengketa Kewenangan Lembaga Negara}

Menurut Bagir Manan, kehadiran lembaga-lembaga negara di dalam dan di luar UUD 1945 merupakan salah satu " produk" reformasi yang bergulir sejak 1998. Sebelum Perubahan UUD 1945, bahkan sepanjang perjalanan RI, tidak ada lembaga negara yang diatur di luar UUD. Terdapat beberapa kemungkinan kehadiran sejumlah lembaga negara yang diatur dan dilahirkan oleh undang-undang. Pertama, pembentuk undang-undang tidak benar-benar memahami kedudukan konstitusional lembaga negara sebagai alat kelengkapan organisasi negara (organ of state, staatorganen) atau alat penyelenggara negara yang bertindak untuk dan atas nama negara. Kedua, menciptakan lembaga negara (walaupun tidak diatur dalam UUD), merupakan suatu cara memberikan status dan privilege yang serupa dengan lembaga negara yang diatur dalam UUD. Ketiga, memberi status suatu badan sebagai lembaga negara, memungkinkan badan tersebut menjalankan kekuasaan sebagai unsur organisasi negara. Keempat, pembentukan lembaga negara baru melalui Perubahan UUD tidak mudah, dibandingkan jika diatur dengan undang-undang. Kelima, pengertian lembaga negara, tidak hanya terbatas pada badan legislatif, eksekutif dan yudikatif. Sudah sejak awal, lembaga negara dalam UUD 1945 tidak hanya eksekutif, legislatif dan yudikatif. Hal serupa dijumpai misalnya, di Perancis, Belanda, Jerman. Keenam, ada kesan, status lembaga negara dipertalikan dengan “independensi" terhadap lembaga-lembaga negara yang diatur dalam UUD. 4

${ }^{4}$ Bagir Manan, "Lembaga-Lembaga di Dalam dan di Luar UUD 1945”, dalam Susi Dwi Harijanti, dkk. (editor), Interaksi Konstitusi dan Politik: Kontekstualisasi Pemikiran Sri Soemantri, Cetakan Pertama, Pusat Studi kebijakan Negara FH Universitas Padjadjaran, Bandung, 2016, hlm. 7. 
Setelah UUD 1945 diubah, terdapat lima bentuk perubahan lembaga negara yang mencakup: (1) Perubahan pengertian lembaga negara; (2) Perubahan kedudukan lembaga negara; (3) Perubahan macam-macam lembaga negara; (4) Perubahan tugas dan wewenang lembaga negara; dan(5) Perubahan hubungan antar lembaga negara. ${ }^{5}$

Menurut Bagir Manan, ada beberapa resiko kehadiran lembaga-lembaga negara di luar UUD yang diatur oleh undang-undang, yaitu: ${ }^{6}$

1. Dapat menimbulkan kerancuan pengertian lembaga negara sebagai organs of state. Kedudukan dan wewenangnya tidak bersifat konstitusional.

2. Eksistensi, susunan, tugas dan wewenang ditentukan (tergantung) kepada pembentuk undang-undang (DPR dan Presiden), seperti upaya mengatur kembali KPK. Termasuk pula kekuasaan pembentuk undang-undang mengadakan berbagai lembaga negara baru.

3. Eksistensi, susunan, tugas dan wewenang lembaga negara yang (hanya) diatur dengan undang-undang, merupakan salah satu objek yang dapat dimohonkan untuk diuji Mahkamah Konstitusi.

4. Karena (hanya) diatur undang-undang, lembaga-lembaga negara di luar UUD sudah semestinya tidak mempunyai kedudukan atau previlege yang sama dengan lembaga-lembaga negara yang diatur di dalam (oleh) UUD.

Satu wewenang yang dilimpahkan pada lembaga negara selalu mempunyai kaitan dengan hukum, yang dapat berwujud UUD, UU maupun peraturan perundang-undangan lainnya. Istilah tugas, fungsi dan wewenang sering dipakai secara interchangeable atau saling dipertukarkan, sehingga kadang-kadang menjadi tidak jelas artinya. ${ }^{7}$

Dalam konteks penyelenggaraan pemerintahan timbulnya sengketa bisa disebabkan beberapa kemungkinan, di antaranya kurang memadainya sistem yang mengatur dan mewadahi hubungan antarorgan yang ada sehingga menimbulkan perbedaan interpretasi. Perbedaan interpretasi terhadap suatu ketentuan yang menjadi bingkai bagi penyelenggaraan negara seringkali menyulut sengketa. Ada banyak penafsiran yang sering digunakan untuk menilai atau memahami suatu konteks permasalahan, di antaranya adalah penafsiran oleh lembaga pengadilan

${ }^{5}$ Ibid., hlm. 8.

${ }^{6}$ Bagir Manan, Lembaga-lembaga..., Op. Cit., hlm.13.

${ }^{7}$ Maruarar Siahaan, Undang-Undang Dasar 1945 Konstitusi Yang Hidup, Sekretariat Jenderal dan Kepaniteraan Mahkamah Konstitusi, Jakarta, 2008, hlm. 424. 
dan penafsiran konstitusional. Terkait dengan sengketa kewenangan, salah satu penafsiran yang dapat digunakan adalah penafsiran konstitusional. ${ }^{8}$ Penafsiran konstitusional merupakan salah satu metode yang sering dipergunakan oleh ahli, bahwa setiap proses keputusan hukum dan kebijakan negara harus dibuat sesuai ketentuan konstitusi. Pada dasarnya prinsip penafsiran konstitusional sama statusnya dengan penafsiran yang dilakukan oleh lembaga peradilan.

Menurut Jimly, dalam sistem ketatanegaraan yang diadopsikan dalam ketentuan UUD 1945 sesudah perubahan, mekanisme hubungan antarlembaga negara bersifat horizontal, tidak lagi bersifat vertikal. Jika sebelum perubahan dikenal adanya lembaga tertinggi negara dan lembaga tinggi negara, maka sekarang tidak ada lagi lembaga tertinggi negara. Hubungan antara satu lembaga dengan lembaga yang lain diikat oleh prinsip checks and balances, di mana lembagalembaga tersebut diakui sederajat tetapi saling mengendalikan satu sama lain. Sebagai akibat adanya mekanisme hubungan yang sederajat itu, timbul kemungkinan dalam melaksanakan kewenangan masing-masing terdapat perselisihan dalam menafsirkan amanat UUD. Jika timbul perselisihan pendapat semacam itu, diperlukan organ tersendiri yang diserahi tugas untuk memutus final atas hal itu. Dalam sistem ketatanegaraan yang telah diadopsikan dalam UUD 1945, mekanisme penyelesaian sengketa kewenangan demikian dilakukan melalui proses peradilan tata negara, yaitu melalui lembaga yang dibentuk tersendiri dengan nama Mahkamah Konstitusi. ${ }^{9}$

Di samping alasan adanya perubahan struktur ketatanegaraan Indonesia saat ini yang kemudian perlu ada penyesuaian dalam mekanisme hubungan antarlembaga negara, kewenangan untuk memutus sengketa kewenangan antarlembaga negara memang diperlukan untuk mencegah agar sengketa tersebut tidak menjadi sengketa politik yang bersifat adversarial. Sebab jika sengketa politik yang justeru terjadi, hal tersebut akan berdampak buruk terhadap mekanisme hubungan kelembagaan antarlembaga negara dan pelaksanaan fungsi dari lembaga negara yang bersengketa tersebut. ${ }^{10}$

\footnotetext{
${ }^{8}$ Ibid., hlm. 22-23.

9 Jimly Asshiddiqie, Sengketa..., Op. Cit., hlm. 3.

${ }_{10}$ Ibid., hlm. 3-4.
} 
Diadakannya mekanisme penyelesaian atas sengketa kewenangan konstitusional antarlembaga negara melalui Mahkamah Konstitusi menunjukkan bahwa penyusun Perubahan UUD NRI Tahun 1945 mengandaikan bahwa dalam dinamika hubungan antarlembaga negara dapat timbul persengketaan pendapat mengenai kewenangan konstitusional masing-masing. Dalam paradigma pemikiran sebelumnya, tidak terbayangkan bahwa antarsesama lembaga negara dapat timbul sengketa kewenangan. Kalau pun timbul perselisihan antara satu lembaga dengan lembaga lain, maka perselisihan semacam itu diselesaikan begitu saja melalui proses-proses politik ataupun kultural, atau setiap masalah yang dihadapi diselesaikan secara politik oleh lembaga atau instansi atasan yang mempunyai kedudukan lebih tinggi dari lembaga yang terlibat persengketaan. Penyelesaian politis dan melalui mekanisme pengambilan keputusan yang bersifat vertikal itulah yang mewarnai corak penyelesaian masalah ketatanegaraan selama ini. ${ }^{11}$

Oleh karena pentingnya prinsip kesetaraan dan independensi lembagalembaga negara yang kewenangannya ditetapkan dalam UUD 1945, maka mekanisme hubungan satu sama lain sangat perlu diatur menurut prinsip-prinsip hukum. Jika timbul persengketaan dalam menjalankan kewenangan konstitusionalnya masing-masing diperlukan lembaga pemutus menurut UUD 1945. Karena itulah UUD 1945 menyediakan mekanisme peradilan khusus untuk mengatasi berbagai kemungkinan timbulnya sengketa kewenangan konstitusional antarlembaga-lembaga negara. Fungsi pemutus itulah yang diamanatkan kepada lembaga Mahkamah Konstitusi sebagai salah satu kewenangannya dalam mengawal tegaknya konstitusi sebagai hukum tertinggi (highest law of the land). ${ }^{12}$

Bagir Manan menyatakan, ada berbagai konsekuensi melakukan penambahan jabatan (lingkungan kerja tetap) dalam suatu organisasi, antara lain: ${ }^{13}$ pertama, dapat menimbulkan tumpang tindih pembagian tugas dan wewenang (taken en bevoegdheid atau rechten en plichten). Lebih-lebih kalau penambahan tersebut tidak disertai dengan rincian tugas dan wewenang yang dapat dibedakan

\footnotetext{
11 Jimly Asshiddiqie, Sengketa..., Op. Cit., hlm. 9.

12 Ibid., hlm. 10-11.

13 Bagir Manan, "Lembaga-lembaga..., Op. Cit., hlm. 10.
} 
dari dan wewenang jabatan yang sudah ada. Kedua, lingkungan jabatan yang bertambah yang disertai pembagian tugas dan wewenang yang tidak jelas, dapat menimbulkan persoalan lain, seperti sengketa wewenang (bevoegdheidsgeschil) atau sebaliknya saling melepas tanggung jawab. Ketidakpastian akibat pembagian tugas wewenang yang tidak jelas, bukan hanya persoalan dalam jabatan atau pelaku jabatan (pejabat). Ketidakpastian akan berakibat pula pada warga. Akibat ada dua lingkungan jabatan (KPK dan Kejaksaan), sebagai penyelidik, penyidik, dan penuntut tindak pidana korupsi, masyarakat tidak mempunyai kepastian antara dua jabatan itu yang dapat benar-benar memperlakukan mereka secara fair untuk menemukan kesalahan dan menjadikan mereka tersangka sebelum tiba di tangan majelis hakim.

Ketiga, khusus untuk birokrasi, penambahan berbagai jabatan atau bermacammacam jabatan dapat menimbulkan birokrasi berlebihan. Birokrasi yang berlebihan, bukan saja menimbulkan inefisiensi dan inefektivitas, melainkan dapat pula menimbulkan rendahnya tanggungjawab (cuci tangan) atau membebani masyarakat yang memerlukan pelayanan dan memudahkan penyalahgunaan kekuasaan serta korupsi. Namun harus pula diakui, jumlah jabatan yang terlalu kecil (sedikit) berhadapan dengan tugas dan wewenang yang banyak dan makin kompleks dapat pula menimbulkan kelambanan dan penyalahgunaan kekuasaan.

Hal senada juga dikemukakan oleh Zainal Arifin Mochtar, kehadiran banyak lembaga negara independen tersebut tentunya memberikan serangkaian implikasi dalam sistem ketatanegaraan dan juga penyelenggaraan pemerintahan di Indonesia. Secara umum implikasi tersebut setidaknya dapat dipilah ke dalam tiga kategori: Pertama, implikasi secara substantif yuridis; Kedua, implikasi administratif yang ditimbulkan; dan Ketiga, implikasi politik sebagai akibat kehadiran lembagalembaga negara independen tersebut. ${ }^{14}$

Salah satu implikasi yang paling serius dari kehadiran lembaga-lembaga negara independen adalah implikasi secara substantif yuridis terhadap penyelenggaraan pemerintahan negara di Indonesia. Implikasi ini detailnya dapat dipetakan menjadi beberapa bagian: (1) implikasi pada posisi institusional lembaga

\footnotetext{
${ }^{14}$ Zainal Arifin Mochtar, Lembaga Negara Independen, Dinamika Perkembangan dan Urgensi Penataannya Kembali Pasca-Amandemen Konstitusi, Rajawali Pers, Jakarta, 2016, hlm. 132.
} 
negara independen; (2) implikasi pada independensi institusional lembaga negara independen; (3) implikasi hubungan lembaga negara independen dengan lembaga negara lainnya; (4) implikasi sengketa kewenangan antar lembaga negara; (5) implikasi pengawasan kelembagaan terhadap lembaga negara independen; (6) implikasi kebutuhan penguatan daya jelajah kelembagaan; dan (7) implikasi pada aturan yang dikeluarkan oleh lembaga negara independen. ${ }^{15}$

Ketidakjelasan dalam pola hubungan antarlembaga negara, telah melahirkan implikasi lanjutan berupa potensi sengketa kewenangan antar lembaga negara. Potensi sengketa ini baik antarlembaga negara independen yang basis kewenangan keduanya ada di konstitusi; kewenangannya tidak dituliskan di konstitusi; lembaga negara yang kewenangannya ada di konstitusi dengan yang tidak dituliskan di dalam konstitusi; atau bisa juga dalam bentuk sengketa kewenangan antar lembaga negara independen dengan lembaga pemerintahan. ${ }^{16}$

Penyelesaian sengketa untuk lembaga negara yang basis kewenangannya ada di konstitusi, sudah jelas jalurnya melalui MK, dengan putusan yang bersifat final dan mengikat atas sengketa tersebut. Namun, bagaimana penyelesaian atas sengketa-sengketa jenis lainnya yang kewenangan tidak diatur oleh konstitusi? Padahal jumlah lembaga negara independen yang sangat banyak dan terkadang memiliki persinggungan kerja kelembagaan, sehingga sangat memungkinkan terjadinya sengketa antar-lembaga negara independen. Besarnya potensi terjadinya sengketa kewenangan kelembagaan negara ini bisa dilihat dari kecenderungan makin meningkatnya jumlah perkara sengketa kewenangan antar-lembaga negara (SKLN) di MK. ${ }^{17}$

Dalam konteks administratif-yuridis, permasalahan yang menyeruak dari ketiadaan cetak biru kelembagaan salah satunya tampak dari kesimpangsiuran nomenklatur dan penamaan lembaga negara independen. Beberapa lembaga menggunakan peristilahan 'dewan', sebagian yang lain menggunakan nama 'komisi', sedangkan lainnya lagi langsung dengan penyebutan nama lembaganya. Dari penelusuran terhadap risalah pembentukan peraturan perundang-undangan yang

15 Ibid., hlm. 133-134.

${ }^{16}$ Ibid., hlm. 141.

${ }^{17}$ Ibid., hlm. 141-142. 
menjadi dasar terbentuknya lembaga dimaksud, sulit untuk menemukan dan melacak alasan mendasar dibalik perbedaan penamaan lembaga-lembaga tersebut. ${ }^{18}$

Adapun implikasi politik yang ditimbulkan dari kehadiran lembaga-lembaga negara independen dapat dilihat dari besarnya hasrat dari kelompok politik, khususnya yang ada di parlemen, untuk menitipkan kepentingan politiknya. Peluang untuk menitipkan kepentingan politik ini terbuka, sebab hampir seluruh proses seleksi atau rekrutmen pimpinan lembaga-lembaga negara independen melibatkan unsur parlemen di dalamnya. Dalam konteks politik, kelahiran lembaga-lembaga ini juga telah memicu munculnya ketegangan dengan lembagalembaga (asli) kekuasaan negara, seperti DPR dan MA. Harus diakui, lahirnya lembaga-lembaga khusus ini telah mencabut sebagian kecil dari kewenangan yang dimiliki dari lembaga-lembaga tersebut. ${ }^{19}$

Dalam konteks Indonesia, yang menyangkut anggota lembaga negara independen (kuasi negara) ini, yang berarti peran aktor, tampaknya memegang peran kunci dalam keberhasilan sebuah lembaga negara menjalankan tugas dan fungsinya. Peran aktor tersebut menjadi makin penting karena pembentukan lembaga negara ini adalah semacam pengakuan terselubung bahwa lembaga-lembaga negara yang ada tidak dapat maksimal menunaikan tugas dan fungsinya. Di samping itu, perlu ditentukan parameter yang jelas untuk mengukur suatu ketentuan yang dihasilkan oleh suatu peraturan perundang-undangan tentang pembentukan lembaga negara itu, misalnya, apa kriteria anggota komisi, bagaimana mereka direkrut, siapa yang merekrut, sejauhmana peranan masyarakat diberi kesempatan untuk memberi masukan pada proses rekrutmen dan seterusnya. ${ }^{20}$

Kegagalan negara lain dalam menjalankan konsep corporatist state (integrated welfare state) berupa pembentukan lembaga-lembaga negara baru selayaknya disikapi secara bijaksana dengan kewaspadaan yang terus dijaga agar kegagalan tersebut tidak menimpa negara Republik Indonesia. Oleh karena itu, desain makro kerangka kelembagaan negara juga harus ditata kembali sesuai dengan cetak biru yang diamanatkan oleh UUD NRI Tahun 1945. Artinya perlu dilakukan

\footnotetext{
${ }^{18}$ Ibid.,, hlm. 119-220.

${ }^{19}$ Ibid., hlm. 220.

${ }^{20}$ Cornelis Lay, Loc. Cit., hlm. 20.
} 
konsolidasi kelembagaan secara menyeluruh dalam rangka menata kembali sistem kelembagaan negara sesuai dengan amanat UUD NRI Tahun 1945. ${ }^{21}$

Pembahasan masalah eksistensi komisi-komisi negara dalam sistem ketatanegaraan menjadi sangat penting pada saat komisi-komisi tersebut akan melaksanakan fungsi, tugas dan kewenangannya sebagai lembaga pembantu negara, yang disekelilingnya telah berdiri lembaga-lembaga negara dengan kedudukannya yang jelas satu sama lain. Strategis tidaknya sebuah komisi akan sangat ditentukan oleh kuat lemahnya kedudukan komisi tersebut dibandingkan lembaga-lembaga negara yang lain. Pengkajian perlu dilakukan untuk melihat apakah komisi-komisi negara memiliki kedudukan yang setara satu sama lain atau sebaliknya. Dalam lingkup yang lebih mendalam, juga penting dikaji apakah komisi-komisi ini berkedudukan sejajar dengan lembaga-lembaga negara lain seperti Presiden, DPR, MPR, dan lain-lain, atau merupakan subordinasi dari lembaga-lembaga negara tersebut. ${ }^{22}$

Untuk itu, menurut Lukman Hakim, pelembagaan komisi negara menurut UUD NRI Tahun 1945 harus didudukkan terlebih dahulu konsep, paradigma, termasuk format kelembagaan negara menurut UUD NRI Tahun 1945. Hal ini akan menjadi pedoman dan acuan dalam menata kelembagaan negara, termasuk di dalamnya pelembagaan komisi-komisi negara. ${ }^{23}$

Membangun konsep, paradigma, dan format kelembagaan dengan pendekatan struktural sudah harus ditinggalkan. Pendekatan ini akan banyak menimbulkan kekacauan pada tahapan implementasi dalam kehidupan penyelenggaraan kehidupan bernegara sehari-hari. Pendekatan fungsional harus digunakan dalam membangun konsep, paradigma, dan format kelembagaan negara secara keseluruhan. ${ }^{24}$

\footnotetext{
${ }^{21}$ Lukman Hakim, Kedudukan Komisi..., Op. Cit., hlm. 227.

22 Ibid., hlm. 7.

${ }^{23}$ Ibid., hlm. 178.

${ }^{24}$ Ibid.
} 


\section{Kewenangan Mahkamah Konstitusi dalam SKLN}

Pada 13 Agustus 2003 dikeluarkanlah UU No. 24 Tahun 2003 tentang Mahkamah Konstitusi. UU ini merupakan pelaksanaan amanat Pasal 24C ayat (6) UUD Negara Republik Indonesia Tahun 1945. Salah satu amanat konstitusional yang dilimpahkan oleh UUD NRI Tahun 1945 kepada Mahkamah Konstitusi adalah wewenang untuk menyelesaikan sengketa kewenangan lembaga negara (SKLN), yang kemudian pelaksanaannya diatur dalam Pasal 10 ayat (1) huruf b Undang-Undang Nomor 24 Tahun 2003 tentang Mahkamah Konstitusi sebagaimana telah diubah dengan Undang-Undang Nomor 8 Tahun 2011 tentang Mahkamah Konstitusi (selanjutnya disebut UU MK), yang berbunyi: "memutus sengketa kewenangan lembaga negara yang kewenangannya diberikan oleh UndangUndang Dasar Negara Republik Indonesia Tahun 1945", yang kemudian diatur dalam Peraturan Mahkamah Nomor 08/PMK/2006 tentang Pedoman Beracara Dalam Sengketa Kewenangan Konstitusional Lembaga Negara.

Pemohon dalam SKLN ditentukan dalam Pasal 61 ayat (1) UU MK adalah lembaga negara yang kewenangannya diberikan oleh UUD Negara Republik Indonesia Tahun 1945 (yang selanjutnya disebut UUD NRI Tahun 1945) yang mempunyai kepentingan langsung terhadap kewenangan yang dipersengketakan. ${ }^{25}$

Sengketa kewenangan antar lembaga negara secara jelas memperoleh batasan bahwa lembaga negara tersebut hanyalah lembaga negara yang memperoleh kewenangannya menurut UUD NRI Tahun 1945, sehingga jelas meskipun dapat terjadi multitafsir dapat dilihat dalam UUD NRI Tahun 1945 lembaga negara mana yang memperoleh kewenangannya secara langsung dari UUD NRI Tahun 1945. Oleh karena UUD adalah juga mengatur organisasi negara dan wewenangnya masing-masing, maka kriteria yang dapat dikemukakan bahwa lembaga negara tersebut harus merupakan organ konstitusi yaitu baik yang dibentuk berdasarkan konstitusi maupun yang secara langsung wewenangnya diatur dan diturunkan dari UUD. ${ }^{26}$

${ }^{25}$ Dengan demikian harus ada hubungan kausal kerugian yang dialami kewenangannya langsung dengan kewenangan yang dilaksanakan oleh lembaga lain.

${ }^{26}$ Maruarar Siahaan, Hukum Acara Mabkamah Konstitusi RI, Konpress, Jakarta, 2005, hlm. 36-37. 
Mengacu kepada pembedaan lembaga negara sebagai organ konstitusi yang memperoleh wewenangnya dari UUD 1945 dan yang bukan, sangat penting untuk diingat bahwa sumber kewenangan tersebut merupakan tolok ukur atau ukuran untuk menentukan corak lembaga negara yang bersengketa menyangkut kewenangannya. Tetapi apakah dengan ukuran yang jelas demikian dapat dikatakan bahwa satu lembaga negara yang memperoleh kewenangannya dari UUD tidak mungkin bersengketa dengan lembaga negara yang memperoleh kewenangan dari undang-undang, dan kalau hal demikian menjadi kenyataan maka hal demikian di luar jurisdiksi MK? Secara pasti hal tersebut belum dapat dikatakan, karena satu lembaga negara yang ditentukan dalam UUD 1945 dengan kewenangan pokok disebut dalam konstitusi, tetapi diatur lebih lanjut dalam undang-undang. Apakah hal pengaturan demikian dalam undang-undang menyebabkan sumber kewenangan secara langsung lembaga negara tersebut dari undang-undang atau dari UUD, masih merupakan perdebatan yang akan memperoleh kepastian dalam kasus-kasus yang dihadapi dan memperoleh putusan yang final dari MK. ${ }^{27}$

Dalam Pasal 1 angka (6) PMK No. 8/2006, Mahkamah memberikan pengertian mengenai kewenangan konstitusional lembaga negara adalah kewenangan yang dapat berupa wewenang/hak dan tugas/kewajiban lembaga negara yang diberikan oleh UUD 1945. Pasal 1 angka (7) PMK No. 8/2006, yang dimaksud dengan sengketa adalah perselisihan atau perbedaan pendapat yang berkaitan dengan pelaksanaan kewenangan antara dua atau lebih lembaga negara. Sesuai dengan Pasal 2 ayat (1) PMK No. 8/2006 menyebutkan bahwa “Lembaga negara yang dapat menjadi Pemohon atau Termohon dalam perkara sengketa kewenangan konstitusional lembaga negara adalah DPR; DPD; MPR; Presiden; BPK; Pemda; atau Lembaga negara lain yang kewenangannya diberikan oleh UUD 1945". Kemudian dalam Pasal 2 ayat (2) ditegaskan, kewenangan yang dipersengketakan adalah kewenangan yang diberikan atau ditentukan oleh UUD 1945.

${ }^{27}$ Maruarar Siahaan, Undang-Undang Dasar 1945..., Op. Cit., hlm. 423. 
Dalam perkara sengketa kewenangan lembaga negara jelas harus disebut dalam permohonan pemohon tentang kepentingan langsung pemohon dan lembaga mana yang menjadi termohon yang merugikan kewenangannya yang diperoleh dari UUD NRI Tahun 1945. Perkara ini tentu berhubungan erat dengan adanya duplikasi atau tumpang tindih kewenangan antara satu lembaga negara dengan lembaga negara lain. Tetapi juga dapat terjadi bahwa kewenangan satu lembaga negara sebagaimana diperoleh dari UUD 1945 telah diabaikan oleh lembaga negara lain baik dalam satu keputusan atau kebijakan negara. ${ }^{28}$

Sesuai dengan PMK No. 8/2006 lembaga negara yang dapat mengajukan sengketa kewenangan sudah diperluas tidak hanya lembaga negara utama tetapi sudah diperluas sampai lembaga negara lain yang kewenangannya diberikan oleh UUD 1945. Hal ini berarti bahwa lembaga negara yang memperoleh kewenangan dari UUD 1945 merupakan sesuatu yang masih open ended, dan membuka ruang tafsir menurut konteks dan dinamika yang dialami dalam kehidupan berbangsa dan bernegara, sebelum memperoleh bentuk final. ${ }^{29}$

Di dalam Pasal 3 PMK No. 08/2006 ditentukan bahwa Pemohon adalah lembaga negara yang menganggap kewenangan konstitusionalnya diambil, dikurangi, dihalangi, dan/atau dirugikan oleh lembaga negara yang lain; Pemohon mempunyai kepentingan langsung terhadap kewenangan yang dipersengketakan; dan Termohon adalah lembaga negara yang dianggap telah mengambil, mengurangi, menghalangi, mengabaikan dan/atau merugikan Pemohon.

Adapun yang menjadi obyek sengketa antarlembaga negara adalah persengketaan mengenai kewenangan konstitusional antarlembaga negara. Isu pokoknya bukan terletak pada kelembagaan lembaga negaranya, melainkan pada soal kewenangan konstitusionalnya, apabila timbul sengketa penafsiran antara satu sama lain. Jadi, pengertian lembaga-lembaga negara yang terkait dengan kewenangan Mahkamah Konstitusi sedemikian banyak jumlahnya dan sedemikian luas cakupan serta jangkauannya. ${ }^{30}$

\footnotetext{
${ }^{28}$ Maruarar Siahaan, Hukum Acara..., Op. Cit., hlm. 162-163.

${ }^{29}$ Lukman Hakim, Kedudukan Hukum..., Op. Cit., hlm. 166.

${ }^{30}$ Jimly Asshiddiqie, Sengketa...,Op. Cit., hlm.49-58. Lihat juga Jimly Asshiddiqie, Perkembangan ..., Loc.Cit.
} 
Untuk itu, mengenai istilah dan terminologi serta tafsir mengenai lembaga negara harus dikaji secara lebih mendalam baik dari segi filosofis, sosiologis, maupun yuridis. Pertama, secara filosofis kelembagaan negara harus dibingkai dari hakekat organisasi negara Republik Indonesia, yakni melalui 2 (dua) kriteria: (1) kriteria tujuan negara RI sebagaimana diamanatkan oleh para pendiri negara; (2) kriteria tujuan organisasi negara secara modern dengan tolok ukur efektif, efisien dan berkeadilan. Kedua, secara sosiologis kelembagaan negara harus mengikuti dan sekaligus mencermati perkembangan lingkungan yang mempengaruhinya. Ketiga, secara yuridis kerangka berfikir bahwa kelembagaan negara merupakan manifestasi dari aspek substantif hukum yang dirumuskan di dalam peraturan perundang-undangan. ${ }^{31}$

Sejak hadirnya Mahkamah Konstitusi (MK) hingga 2016 telah ada 25 permohonan sengketa kewenangan lembaga negara yang diajukan ke MK dengan persoalan yang sangat beragam. Lembaga negara yang mengajukan sengketa kewenangan ke MK tidak terbatas pada lembaga negara utama (main organ) saja, yakni Majelis Permusyawaratan Rakyat (MPR), Dewan Perwakilan Rakyat (DPR), Dewan Perwakilan Daerah (DPD), Komisi Yudisial (KY), Badan Pemeriksa Keuangan (BPK), Presiden, dan Mahkamah Agung (MA). Kasus-kasus sengketa kewenangan yang muncul dalam praktik ketatanegaraan telah meluas pada lembaga-lembaga independen maupun lembaga-lembaga di daerah. Misalnya sengketa antara lembaga negara antara Gubernur Provinsi Lampung dengan DPRD Provinsi Lampung, ${ }^{32}$ Ketua dan Wakil Ketua DPRD Poso Provinsi Sulawesi Tengah dengan Gubernur Provinsi Sulawesi Tengah,33 Komisi Penyiaran Indonesia dengan Menteri Komunikasi dan Informatika, Komisi Independen Pemilu Tingkat Kabupaten Aceh Tenggara dan DPRD Kabupaten Aceh Tenggara,34 Bawaslu

\footnotetext{
${ }^{31}$ Lukman Hakim, Kedudukan Hukum ..., Op. Cit., hlm. 167-168.

32 Lihat Ketetapan Perkara No. 025/SKLN-III/2005 tentang Penarikan Kembali Sengketa Kewenangan Gubernur Provinsi Lampung dengan DPRD Provinsi Lampung, tertanggal 5 Januari 2006.

${ }^{33}$ Lihat Putusan Perkara No. 027/SKLN-IV/2006 tentang Sengketa Kewenangan Antara Ketua dan Wakil Ketua DPRD Poso Provinsi Sulawesi Tengah terhadap Gubernur Provinsi Sulawesi Tengah, tertanggal 12 Mei 2007.

34 Lihat Putusan Perkara No. 026/SKLN-V/2007 tentang Sengketa Kewenangan Antara KIP Tingkat Kabupaten Aceh Tenggara dan DPRD Kabupaten Aceh Tenggara, tertanggal 11 Maret 2008.
} 
dengan DPRD Nanggroe Aceh Darussalam dan Gubernur Nanggroe Aceh Darusalam, ${ }^{35}$ dan lain-lain.

Bahkan ada beberapa kasus yang timbul sebagai sengketa kewenangan konstitusional antarlembaga negara, akan tetapi objek yang dipersoalkan tidak selalu dikaitkan dengan soal kewenangan, tetapi diajukannya perkara melalui 'pintu' pengujian undang-undang, misalnya dalam perkara sengketa kewenangan terhadap pengawasan perilaku hakim antara MA dengan KY; ${ }^{36}$ kasus pemekaran daerah Provinsi Sulawesi Barat dari Provinsi Sulawesi Selatan; ${ }^{37}$ kasus hak pemerintah daerah untuk ikut mengembangkan sistem jaminan sosial. ${ }^{38}$ Bahkan ada pengajuan sengketa lembaga negara yang sebelumnya didahului dengan pengajuan permohonan pengujian undang-undang oleh pemohon yang sama, misalnya kasus sengketa hasil Pilkada Depok, ${ }^{39}$ dan Komisi Penyiaran Indonesia.

Di dalam praktik permohonan sengketa kewenangan lembaga negara di Mahkamah Konstitusi, juga pernah terjadi penarikan kembali permohonan oleh pihak pemohon, misalnya yang diajukan oleh: Pertama, Gubernur Provinsi Lampung dalam sengketa kewenangan antara Gubernur Provinsi Lampung dengan DPRD Provinsi Lampung, dengan alasan situasi atau kondisi di Provinsi Lampung cenderung membaik. ${ }^{40}$ Kedua, sengketa kewenangan antara BI dengan KPK terkait proses pemanggilan dan penyidikan Gubernur BI. Dalam kasus ini akhirnya juga terjadi penarikan kembali permohonan oleh pihak pemohon setelah mendengarkan saran Hakim pada sidang Pemeriksaan Pendahuluan tanggal 21 Februari 2008. Panel Hakim memberikan tiga alternatif terhadap perkara a quo antara lain, untuk dicabut dan dicari saluran yang pas, diperbaiki, atau tetap pada

\footnotetext{
${ }^{35}$ Lihat Putusan Perkara Nomor 3/SKLN-XI/2013 tentang Sengketa Kewenangan antara Bawaslu dengan DPRD Nanggroe Aceh Darussalam dan Gubernur Nanggroe Aceh Darusalam.

${ }^{36}$ Lihat Putusan Perkara No. 05/PUU- IV / 2006 Tentang Pengawasan KY Terhadap Hakim Agung dan Hakim Konstitusi, tertanggal 23 Agustus 2006.

${ }^{37}$ Lihat Putusan Perkara No. 070/PUU-II/2004 tentang Kewajiban Provinsi Induk terhadap Provinsi Pemekaran, tertanggal 12 April 2005.

38 Lihat Putusan Perkara No. 007/PUU-III/2005 tentang Hak Pemerintah Daerah Untuk Ikut Mengembangkan Sistem Jaminan Sosial, tertanggal 31 Agustus 2005.

${ }^{39}$ Lihat Putusan Perkara No. 001/PUU-IV/2006 tentang Pengujian Putusan Peninjauan Kembali MA Mengenai Hasil Pemilihan Kepala Daerah Depok, tertanggal 25 Januari 2006.

40 Ketetapan Perkara No. 025/SKLN-III/2005 tentang Penarikan Kembali Sengketa Kewenangan Gubernur Provinsi Lampung dengan DPRD Provinsi Lampung, tertanggal 5 Januari 2006.
} 
permohonan semula. ${ }^{41}$ Ketiga, sengketa antara KPUD Provinsi Maluku Utara dengan KPU.42 Keempat, sengketa antara KPU Kabupaten Labuhanbatu Selatan dengan KPU Provinsi Sumatera Utara. ${ }^{43}$

Rekapitulasi Sengketa Kewenangan Lembaga Negara Mahkamah Konstitusi Republik Indonesia Tahun 2004 S.D 10 Agustus 2016

\begin{tabular}{|c|c|c|c|c|c|c|c|c|c|c|}
\hline \multirow{2}{*}{ No. } & \multirow{2}{*}{ Tahun } & \multirow{2}{*}{$\begin{array}{l}\text { Sisa } \\
\text { yang } \\
\text { Lalu }\end{array}$} & \multirow{2}{*}{\multicolumn{2}{|c|}{ Terima Jumlah }} & \multicolumn{4}{|c|}{ Putus } & \multirow{2}{*}{$\begin{array}{l}\text { Jumlah } \\
\text { Putusan }\end{array}$} & \multirow{2}{*}{$\begin{array}{l}\text { Sisa } \\
\text { tahun } \\
\text { Ini }\end{array}$} \\
\hline & & & & & Kabul & Tolak & $\begin{array}{c}\text { Tidak } \\
\text { Diterima }\end{array}$ & $\begin{array}{c}\text { Tarik } \\
\text { Kembali }\end{array}$ & & \\
\hline 1 & 2004 & 0 & 1 & 1 & 0 & 1 & 0 & 0 & 1 & 0 \\
\hline 2 & 2005 & 0 & 1 & 1 & 0 & 0 & 0 & 0 & 0 & 1 \\
\hline 3 & 2006 & 1 & 4 & 5 & 0 & 0 & 2 & 1 & 3 & 2 \\
\hline 4 & 2007 & 2 & 2 & 4 & 0 & 1 & 1 & 0 & 2 & 2 \\
\hline 5 & 2008 & 2 & 3 & 5 & 0 & 0 & 2 & 2 & 4 & 1 \\
\hline 6 & 2009 & 1 & 0 & 1 & 0 & 0 & 1 & 0 & 1 & 0 \\
\hline 7 & 2010 & 0 & 1 & 1 & 0 & 0 & 0 & 0 & 0 & 1 \\
\hline 8 & 2011 & 1 & 6 & 7 & 0 & 0 & 4 & 0 & 4 & 3 \\
\hline 9 & 2012 & 3 & 3 & 6 & 1 & 1 & 3 & 1 & 6 & 0 \\
\hline 10 & 2013 & 0 & 3 & 3 & 0 & 0 & 2 & 0 & 2 & 1 \\
\hline 11 & 2014 & 1 & 0 & 1 & 0 & 0 & 1 & 0 & 1 & 0 \\
\hline 12 & 2015 & 0 & 1 & 1 & 0 & 0 & 0 & 1 & 1 & 0 \\
\hline 13 & 2016 & 0 & 0 & 0 & 0 & 0 & 0 & 0 & 0 & 0 \\
\hline & Jumlah & & 25 & - & 1 & 3 & 16 & 5 & 25 & - \\
\hline
\end{tabular}

Sumber: Diolah dari data laman Mahkamah Konstitusi RI.

Berdasarkan praktik, sengketa kewenangan konstitusional lembaga negara dapat terjadi karena beberapa hal:44

a. Adanya tumpang tindih (overlapping) kewenangan antara satu lembaga negara dengan lembaga negara lainnya yang diatur dalam konstitusi atau UndangUndang Dasar;

b. Adanya kewenangan lembaga negara yang kewenangannya diperoleh dari konstitusi atau Undang-Undang Dasar yang diabaikan oleh lembaga negara lainnya.

41 Ketetapan Perkara No. 07/SKLN-VI/2008 tentang Penarikan Kembali Permohonan Sengketa Kewenangan Antara BI terhadap KPK, tertanggal 18 Maret 2008.

42 Ketetapan Perkara No. 032/SKLN-V/2007 tentang Penarikan Kembali Permohonan Sengketa Kewenangan Lembaga Negara Antara KPU Provinsi Maluku Utara Terhadap KPU, tertanggal 21 Januari 2008.

43 Ketetapan Perkara No. 01/SKLN-XIII/2015 tentang Penarikan Kembali Permohonan Sengketa Kewenangan Lembaga Negara Antara KPU Kabupaten Labuhanbatu Selatan dengan KPU Provinsi Sumatera Utara, tertanggal 13 Oktober 2015.

44 Tim Penyusun Hukum Acara Mahkamah Konstitusi, Hukum Acara Mabkamah Konstitusi, Sekretariat Jenderal dan Kepaniteraan Mahkamah konstitusi, Jakarta, 2010, hlm. 172. 
c. Adanya kewenangan lembaga negara yang kewenangannya diperoleh dari konstitusi atau Undang-Undang Dasar yang dijalankan oleh lembaga negara lainnya, dan sebagainya.

Dari permohonan sengketa kewenangan lembaga negara yang diajukan ke Mahkamah Konstitusi sejak tahun 2004 sampai dengan 10 Agustus 2016 ada sebanyak 25 (dua puluh lima) perkara. Dari 25 (duapuluh lima) perkara tersebut, ada 5 (lima) putusan yang mengabulkan pemohon untuk menarik kembali permohonannya; 1 (satu) perkara permohonannya ditolak seluruhnya; 18 (delapan belas) perkara permohonan pemohon tidak dapat diterima (niet ontvankelijk verklaard/NO); dan hanya ada 1 (satu) permohonan yang dikabulkan, yakni Perkara No. 03/SKLN-X/2012, yaitu sengketa kewenangan antara KPU dengan pemerintah daerah Papua, yakni DPR Papua (Termohon I) dan Gubernur Papua (Termohon 2).

Dari kajian di atas dapat disimpulkan bahwa urgensitas perluasan para pihak dalam sengketa kewenangan lembaga negara di Mahkamah Konstitusi adalah untuk memberi payung hukum yang jelas terhadap kasus-kasus sengketa kewenangan lembaga negara melalui jalur hukum dan bukan melalui jalur politik.

\section{Penutup}

Setelah melakukan kajian atas permasalahan yang diteliti dapatlah disimpulkan, pertama, munculnya sengketa kewenangan lembaga negara disebabkan: (1) adanya tumpang tindih (overlapping) kewenangan antara satu lembaga negara dengan lembaga negara lainnya yang diatur dalam konstitusi atau Undang-Undang Dasar; (2) Adanya kewenangan lembaga negara yang kewenangannya diperoleh dari konstitusi atau Undang-Undang Dasar yang diabaikan oleh lembaga negara lainnya. (3) Adanya kewenangan lembaga negara yang kewenangannya diperoleh dari konstitusi atau Undang-Undang Dasar yang dijalankan oleh lembaga negara lainnya, dan sebagainya. Kedua, meskipun Mahkamah Konstitusi telah menyidangkan permohonan sengketa lembaga negara sebanyak 25 perkara, namun Mahkamah Konstitusi hanya mengabulkan 1 (satu) perkara yakni yakni Perkara No. 03/SKLN-X/2012, yaitu sengketa kewenangan antara KPU dengan Pemerintah Daerah Papua, yakni DPR Papua (Termohon I) dan Gubernur Papua (Termohon 2). 
Mengingat dinamika perkembangan lembaga negara pasca reformasi yang luar biasa serta kebutuhan untuk memecahkan persoalan bangsa yang tidak dapat diserahkan kepada lembaga lain, maka diusulkan supaya tafsir yang sempit dan restriktif terhadap legal standing pemohon ditinggalkan, untuk menyesuaikan dengan tuntutan kebutuhan dan perkembangan zaman.

\section{Daftar Pustaka}

\section{Buku}

Arifin, Firmansyah, dkk., Lembaga Negara dan Sengketa Kewenangan Antarlembaga Negara, KRHN bekerjasama dengan MKRI didukung oleh The Asia Foundation dan USAID, Jakarta, Juni 2005.

Arifin Mochtar, Zainal, Lembaga Negara Independen, Dinamika Perkembangan dan Urgensi Penataannya Kembali Pasca-Amandemen Konstitusi, Rajawali Pers, Jakarta, 2016.

Asshiddiqie, Jimly, Sengketa Kewenangan Antarlembaga Negara, Konpress, Jakarta, 2005.

- Perkembangan dan Konsolidasi Lembaga Negara Pasca Reformasi, Sekretarian Jenderal dan Kepaniteraan Mahkamah Konstitusi RI, Jakarta, 2006.

Menuju Negara Hukum Yang Demokratis, Sekretariat Jenderal dan Kepaniteraan Mahkamah konstitusi, Jakarta, 2008.

Dwi Harijanti, Susi, dkk. (editor), Interaksi Konstitusi dan Politik: Kontekstualisasi Pemikiran Sri Soemantri, Cetakan Pertama, Pusat Studi kebijakan Negara FH Universitas Padjadjaran, Bandung, 2016.

Hakim, Lukman, Kedudukan Komisi Negara Di Indonesia: Eksistensi Komisi-komisi Negara (State Auxiliary Agency) Sebagai Organ Negara yang Mandiri Dalam Sistem Ketatanegaraan, Program Pasca Universitas Brawijaya, Malang, 2010.

Mukthie Fadjar, Abdul, Hukum Konstitusi dan Mahkamah Konstitusi, Sekretariat Jenderal dan Kepaniteraan Mahkamah Konstitusi RI, Jakarta, 2006.

Siahaan, Maruarar, Hukum Acara Mahkamah Konstitusi RI, Konpress, Jakarta, 2005.

, Undang-Undang Dasar 1945 Konstitusi Yang Hidup, Sekretariat Jenderal dan Kepaniteraan Mahkamah Konstitusi, Jakarta, 2008

Tim Penyusun Hukum Acara Mahkamah Konstitusi, Hukum Acara Mahkamah Konstitusi, Sekretariat Jenderal dan Kepaniteraan Mahkamah konstitusi, Jakarta, 2010

\section{Jurnal}

Lay, Cornelis, "State Auxiliary Agencies", Jurnal Hukum JENTERA, Edisi 12 Tahun III April-Juni 2006. 


\section{Putusan Pengadilan}

Putusan Perkara No. 070/PUU-II/2004 tentang Kewajiban Provinsi Induk terhadap Provinsi Pemekaran, tertanggal 12 April 2005.

Putusan Perkara No. 007/PUU-III/2005 tentang Hak Pemerintah Daerah Untuk Ikut Mengembangkan Sistem Jaminan Sosial, tertanggal 31 Agustus 2005.

Putusan Perkara No. 001/PUU-IV/2006 tentang Pengujian Putusan Peninjauan Kembali MA Mengenai Hasil Pemilihan Kepala Daerah Depok, tertanggal 25 Januari 2006.

Putusan Perkara No. 05/PUU- IV / 2006 Tentang Pengawasan KY Terhadap Hakim Agung dan Hakim Konstitusi, tertanggal 23 Agustus 2006.

Putusan Perkara No. 027/SKLN-IV/2006 tentang Sengketa Kewenangan Antara Ketua dan Wakil Ketua DPRD Poso Provinsi Sulawesi Tengah terhadap Gubernur Provinsi Sulawesi Tengah, tertanggal 12 Mei 2007.

Putusan Perkara No. 030/SKLN-IV/2006 tentang Sengketa Kewenangan Antara Komisi Penyiaran Indonesia dengan Menteri Komunikasi dan Informatika, tertanggal 17 April 2007.

Putusan Perkara No. 026/SKLN-V/2007 tentang Sengketa Kewenangan Antara KIP Tingkat Kabupaten Aceh Tenggara dan DPRD Kabupaten Aceh Tenggara, tertanggal 11 Maret 2008.

Putusan Perkara Nomor 3/SKLN-XI/2013 tentang Sengketa Kewenangan antara Bawaslu dengan DPRD Nanggroe Aceh Darussalam dan Gubernur Nanggroe Aceh Darusalam.

Ketetapan Perkara No. 025/SKLN-III/2005 tentang Penarikan Kembali Sengketa Kewenangan Gubernur Provinsi Lampung dengan DPRD Provinsi Lampung, tertanggal 5 Januari 2006.

Ketetapan Perkara No. 032/SKLN-V/2007 tentang Penarikan Kembali Permohonan Sengketa Kewenangan Lembaga Negara Antara KPU Provinsi Maluku Utara Terhadap KPU, tertanggal 21 Januari 2008.

Ketetapan Perkara No. 07/SKLN-VI/2008 tentang Penarikan Kembali Permohonan Sengketa Kewenangan Antara BI terhadap KPK, tertanggal 18 Maret 2008.

Ketetapan Perkara No. 01/SKLN-XIII/2015 tentang Penarikan Kembali Permohonan Sengketa Kewenangan Lembaga Negara Antara KPU Kabupaten Labuhanbatu Selatan dengan KPU Provinsi Sumatera Utara, tertanggal 13 Oktober 2015. 